\title{
EXPERIMENTAL STUDY ON CHITOSAN COMPOSITE FLOCCULANT FOR TREATING PAPERMAKING WASTEWATER
}

\author{
D. Zeng, D. Hu, J. Cheng
}

School of Resource and Environmental Engineering, Wuhan University of Technology, P.R. China

Recieved 04.03.2011

In this paper, the flocculation effect of a novel composite flocculant for treating papermaking wastewater was studied and discussed. Results indicated that it achieved the best flocculation effect when this composite flocculant consisting of $60 \mathrm{mg} / \mathrm{L}$ of polymerized ferrous sulfate, $2 \mathrm{mg} / \mathrm{L}$ of polyacrylamide and $0.4 \mathrm{mg} / \mathrm{L}$ of chitosan, and pH value of wastewater was adjusted to 7.5. It also observed that the removal rate of chemical oxygen demand (COD) and solid substances (SS) with this novel composite flocculant reached $72.5 \%$ and $98.5 \%$ respectively. Compared with the conventional flocculant such as polyacrylamide/ polyaluminium chloride, the percentage of removing COD and SS using this composite flocculant were increased by 15.2 and $6.4 \%$ respectively, moreover, its input cost was cut down 18.4\%. So this compositeflocculant has significantly environmental and economic benefits.

Keywords: composite flocculant, flocculation, papermaking wastewater.

\section{Introduction}

Papermaking industry is one of six industrial pollution sources in the world. Papermaking wastewater has a large amount of discharge, high concentration of pollutants, poor biodegradation and strong toxicity [ $1-3]$. And it contains the massive phenol, halogenated hydrocarbon and many other kinds of persistent organic pollutants in papermaking wastewater. So, to solve the pollution problem of papermaking wastewater has aroused the concern from the whole society.

As a physical chemical method, flocculation is widely used to treat papermaking wastewater because of its simple technology, upstanding effect in persistent organic pollutants, some fine particles, chromaticity and turbidity, low cost as well $[4,5]$. Current flocculants are generally classified into three categories, inorganic, organic and composite flocculants. The obvious disadvantages of inorganic flocculants, like polyaluminium chloride, are its large applied dosage 
and high cost for single use [6,7]. For organic flocculants with good water purification property, such as polyacrylamide, hard degradability and toxic residual monomer are two main constrains of organic flocculants for industrialized applications. For composite flocculants including polyacrylamide / polyaluminium chloride, although it has excellent treatment effect, there are still negative factors like residual poisonous chemicals and high price [8 - 10]. Thus, a novel composite flocculant consisting of polymerized ferrous sulfate, polyacrylamide and chitosan was prepared to treat papermaking wastewater in this research. Compared with the conventional flocculant such as polyacrylamide/polyaluminium chloride, the percentage of removing COD and SS in the treated water using this novel composite flocculant were enhanced by $15.2 \%$ and $6.4 \%$ respectively, and the input cost was decreased by $18.4 \%$, showing significant application values and market prospects in papermaking wastewater treatment fields.

\section{Materials and methods}

Materials. Polymerized ferrous sulfate (PFS) was obtained from Nanjing Fine Chemical Company of P.R.China. Polyacrylamide (PAM) was purchased from Daqing Fine Chemical Company of P.R.China. Chitosan (CTS) was obtained from Qingdao Biochemical Company of P.R.China. Polyaluminum chloride (PAC) was obtained from Nanjing Fine Chemical Company of P.R.China. All chemicals are analysis pure.

Raw water. The raw water from Chenming Paper Mill in Wuhan of P.R. China, COD $=1270 \mathrm{mg} / \mathrm{L}$, turbidity value $=18889 \mathrm{NTU}, \mathrm{SS}=1790 \mathrm{mg} / \mathrm{L}$, $\mathrm{pH} 7.5$, water temperature about $35^{\circ} \mathrm{C}$. The raw water within a lot of fiber and suspended solids is cloudy and dark brown.

Flocculation experiment. Composite flocculants with PFS/PAM/CTS of different dosage were designed as $1^{\#}-6^{\#}$. After treating $300 \mathrm{ml}$ raw water with flocculation test mixing apparatus (Model TA6-2, Hengling Science and Technology Co. Ltd., Wuhan, P.R. China) under the same conditions, kept the wastewater resting for a while, then the upper fluid was used to measure the concentrations of COD and SS in the treated water samples so as to determine the removal rate of COD and SS.

\section{Experimental and analytic methods}

Comparative experiment of composite flocculant with six designed formulations was conducted to select formula with highest removal rate of COD and SS. By investigating the influence of $\mathrm{pH}$ value, reaction temperature, stirring speed and mixing time on coagulating effect, the optimal formula and process could be determined. After comparing the composite flocculant with the best 
formulas to the traditional flocculant on performance-price ratio, the characteristics and properties of the composite flocculant was achieved last.

In each experiment, raw water with $300 \mathrm{ml}$ were dispensed into six beakers, after stirring at a certain velocity for a few minutes on a coagulation test mixing apparatus, kept the wastewater resting for a while, then the upper fluid was used to measure the concentrations of COD and SS in the treated water samples. The COD and SS determination were done by means of COD digestion device (Model XJ-1, Environmental Protection Apparatus and Equipments Plant, Guangdong, P.R.China) and scattering-type optoelectronic turbidity meter (Model WGZ-100, Jinziguang Apparatus Corp., Beijing, P.R. China) respectively. The concentrations of COD and SS were measured according to the Water Quality Suspension Measuring Method(GB-11901-89) and Hydrochemistry Oxygen Requirement Measuring Method (GB-11914-89).

\section{Results and discussion}

Confirming the optimal dosage of composite flocculant. To determine the effect on COD and SS removal using composite flocculant, we initially conducted tests to determine the optimal dosage of composite flocculant. We prepared six kinds of composite flocculant (Table 1). And the optimal one was determined. The results indicated that the optimal dosage was $4^{\#}$ composite flocculant (Table 2). And the optimal dosage of composite flocculant was $60 \mathrm{mg} / \mathrm{L}$ of polymerized ferrous sulfate, $2 \mathrm{mg} / \mathrm{L}$ of polyacrylamide and $0.4 \mathrm{mg} / \mathrm{L}$ of chitosan. The removal rate of COD and SS were enhanced with the increased dosage of composite flocculant. And the removal rate of COD and SS reached the highest level when treated by $4^{\#}$ flocculant formula. The optimal removal efficiency of COD and SS were $62.1 \%$ and $88.7 \%$ respectively.

Table 1. Dosage of 6 kinds of composite flocculant

\begin{tabular}{|c|c|c|c|}
\hline \multirow{2}{*}{ No. of flocculant } & Dosage of PFS & Dosage of PAM & Dosage of CTS \\
\cline { 2 - 4 } & \multicolumn{3}{|c|}{$\mathrm{mg} / \mathrm{L}$} \\
\hline $1^{\#}$ & 10 & 0.5 & 0.1 \\
\hline $2^{\#}$ & 20 & 1.0 & 0.2 \\
\hline $3^{\#}$ & 40 & 1.5 & 0.3 \\
\hline $4^{\#}$ & 60 & 2.0 & 0.4 \\
\hline $5^{\#}$ & 80 & 2.5 & 0.5 \\
\hline $6^{\#}$ & 100 & 3.0 & 0.6 \\
\hline
\end{tabular}


Table 2. Comparison of the flocculation effect of 6 kinds of composite flocculant

\begin{tabular}{|c|c|c|c|}
\hline No. & No. of flocculant & $\begin{array}{c}\text { Removal rate of } \\
\text { COD (\%) }\end{array}$ & $\begin{array}{c}\text { Removal rate of } \\
\text { SS (\%) }\end{array}$ \\
\hline 1 & $1^{\#}$ & 56.7 & 73.3 \\
\hline 2 & $2^{\#}$ & 56.2 & 82.5 \\
\hline 3 & $3^{\#}$ & 60.5 & 84.9 \\
\hline 4 & $4^{\#}$ & 62.1 & 88.7 \\
\hline 5 & $5^{\#}$ & 60.7 & 88.0 \\
\hline 6 & $6^{\#}$ & 60.2 & 86.6 \\
\hline
\end{tabular}

Confirming the optimal treatment conditions of composition flocculant. Optimization experiments of the composite flocculant based on $4^{\#}$ flocculant formulas was conducted with the following effect factors to determine the appropriate treatment conditions that led to the best removal rate of COD and SS.

Confirming the optimal $\mathrm{pH}$ value. $\mathrm{pH}$ value plays a critical role in flocculation effect. A series of tests were conducted to study the flocculation effectiveness of composite flocculant under various $\mathrm{pH}$ value conditions. Fig. 1 showed that the optimal flocculation effect of composite flocculant at $\mathrm{pH}$ value 7.5. And the removal rate of COD and SS varied with $\mathrm{pH}$ value that followed a curve. The removal rate of COD and SS reached the highest level in the range of $\mathrm{pH} 6.5$ to 8.5 . We attribute it to that chitosan would be dissolved when $\mathrm{pH}$ value was less than 6.5 and it affected the flocculation effect. Besides, alkaline substance would polymerize and subside with PFS in raw water and led to the removal rate of COD and SS was reduced when $\mathrm{pH}$ value exceeded $6.5[11]$.

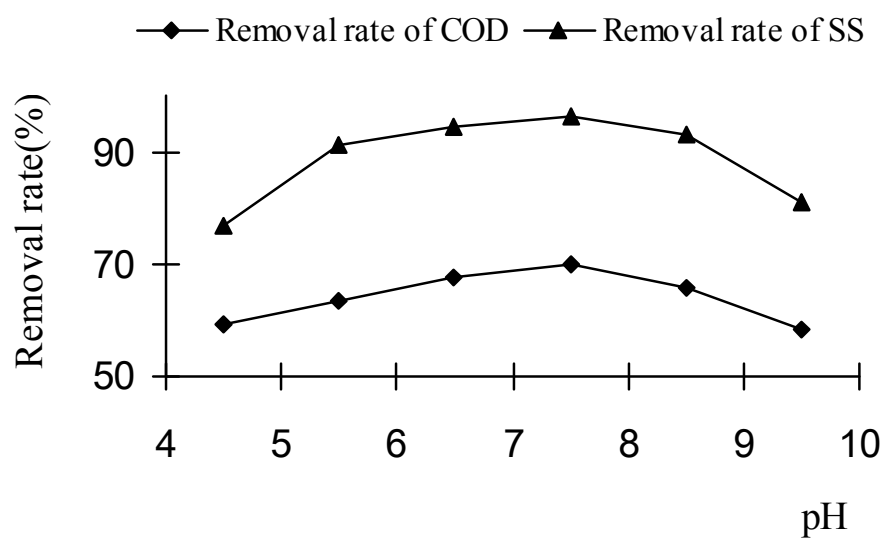

Fig. 1. Influence of $p H$ value on removing COD and SS. 
Confirming the optimal reaction temperature. Temperature has a direct influence on flocculation effect. It is a disadvantage to flocculation effectiveness when the temperature is too high or too low. The water temperature is too high would accelerate the chemical reaction, product fine flocs and increase the hydration of flocs. But it will consume a lot of energy and rise cost when the water heats up. Nevertheless, the water temperature is too low would increase the hydrolysis time of some flocculant. It affects the flocculation effectiveness without prolonging the time. We conducted the tests to determine the optimal reaction temperature of composite flocculant (Fig. 2). The results of the experiment showed that the removal rate of COD was enhanced when the reaction temperature in the range from $20^{\circ} \mathrm{C}$ to $35^{\circ} \mathrm{C}$, however, the removal rate of SS had not a obvious change when the temperature was between $20^{\circ} \mathrm{C}$ and $45^{\circ} \mathrm{C}$. And the removal rate of COD and SS reached the highest level when the temperature was $35^{\circ} \mathrm{C}$. So, we selected $35^{\circ} \mathrm{C}$ as the optimal reaction temperature. As the temperature of the papermaking wastewater was $35^{\circ} \mathrm{C}$, there was no need to adjust the temperature.

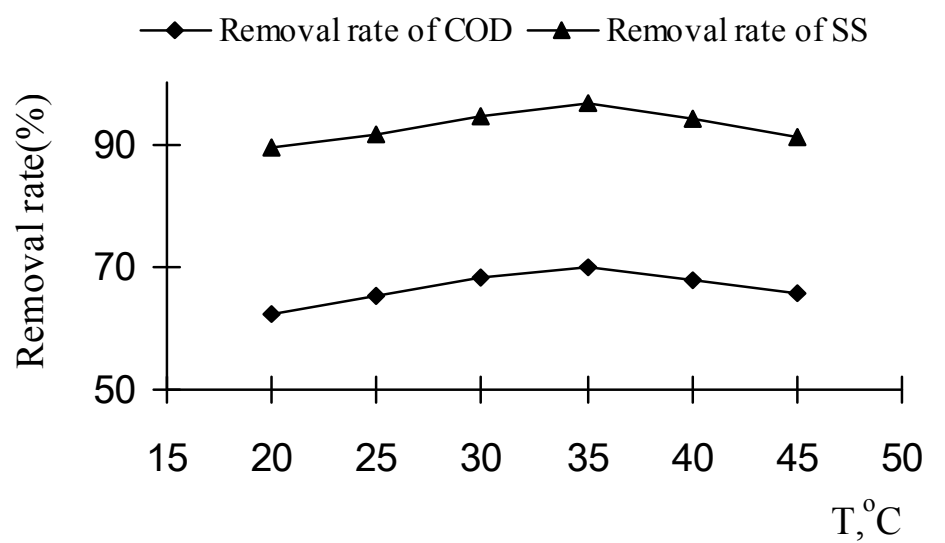

Fig. 2. Influence of reaction temperature on removing COD and SS.

Confirming the optimal stirring speed. The hydraulic condition has a great influence on forming flocs. The stirring speed can change the hydraulic condition so that it will affect the flocculation effect. The flocculation process can be divided into two stages: mixing and reaction. The stirring speed was critical to the formation of flocs in the two stages. A series of tests were conducted to study the flocculation effectiveness of composite flocculant under various stirring speed. Fig. 3 showed that the optimal flocculation effect of composite flocculant at the rapid stirring speed of $100 \mathrm{r} / \mathrm{min}$. And the removal rate of COD and SS were $70.5 \%$ and $96.8 \%$ respectively that reached the highest level. Fig. 4 showed that the optimal coagulation effect of composite flocculant at the slow stirring speed of $50 \mathrm{r} / \mathrm{min}$. And the removal rate of COD and SS were $71.3 \%$ and $97.2 \%$ respectively. The reasons could be explained by the mechanism of flocculation, 
on one hand, composite flocculant reacted with substance which consumed oxygen directly and formed flocs. On the other hand, composite flocculant adsorbed the substance in the raw water by the function of bridging and netcapture [12]. Therefore, macromolecule flocs would be broken up when the mixing speed was too fast, and led to reducing the removal rate of COD and SS.

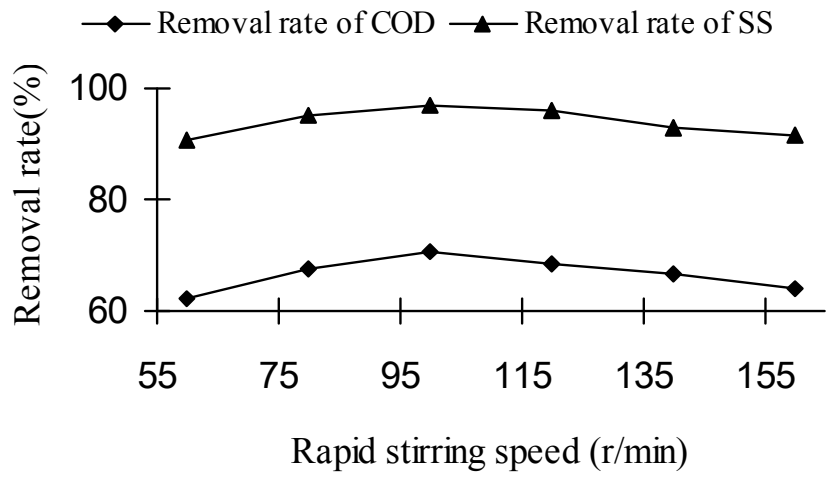

Fig. 3. Influence of rapid stirring speed on removing COD and SS.
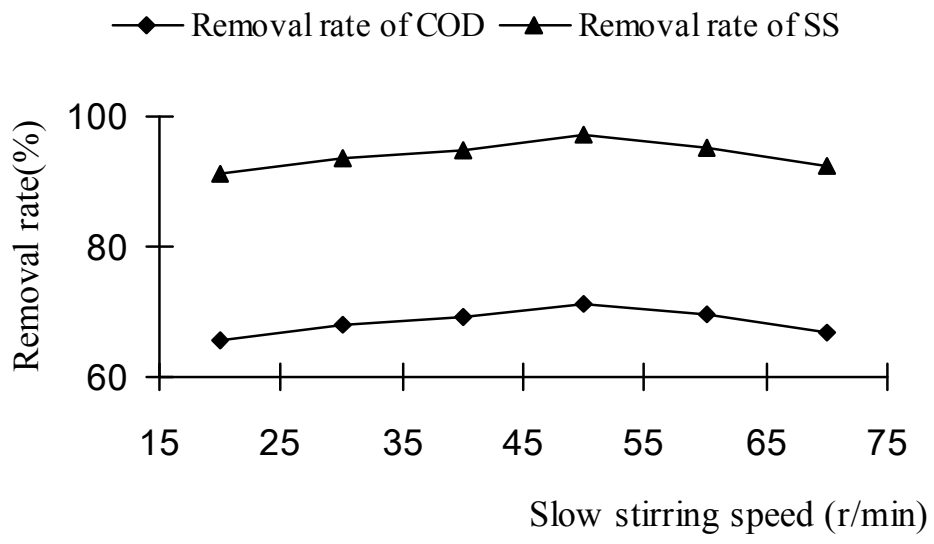

Fig. 4. Influence of slow stirring speed on removing COD and SS.

Confirming the optimal mixing time. To determine the influence of mixing time to flocculation effect, we conducted tests under various mixing time. Fig. 5 showed that the optimal flocculation effect of composite flocculant at the rapid mixing time for $2 \mathrm{~min}$. And the removal rate of COD and SS reached the highest level which was $72.0 \%$ and $97.9 \%$ respectively. Fig. 6 showed that the optimal flocculation effect of composite flocculant at the slow mixing time for $8 \mathrm{~min}$. And the removal rate of COD and SS reached the highest level which was $72.5 \%$ and $98.5 \%$ respectively. It was because that the mixing stage should at the rapid stirring speed in the flocculation process so that flocculant would 
spread into the water rapidly and evenly and made colloid particles to coagulation. As the formation of fine aggregate was completed in a few minutes, it would break up the formed fine aggregate and affected interpretive flocculation if the mixing time was too long [13]. In addition, it needed slow stirring the water for a while when reaction stage made the particles to forming large flocs. The mixing time could not last too long as it could be bad for the formation of the flocs.

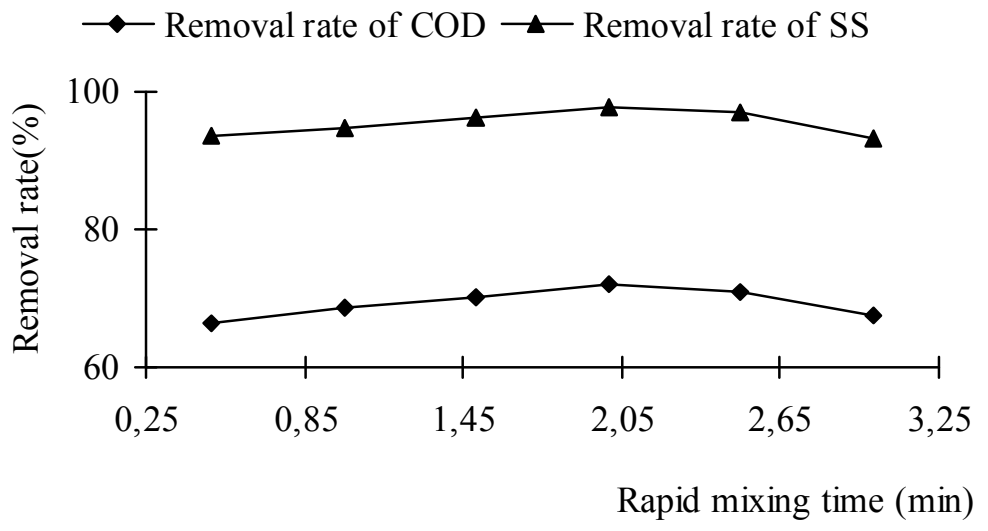

Fig. 5. Influence of rapid mixing time on removing COD and SS.

$\longrightarrow$ Removal rate of COD $\neg$ Removal rate of SS

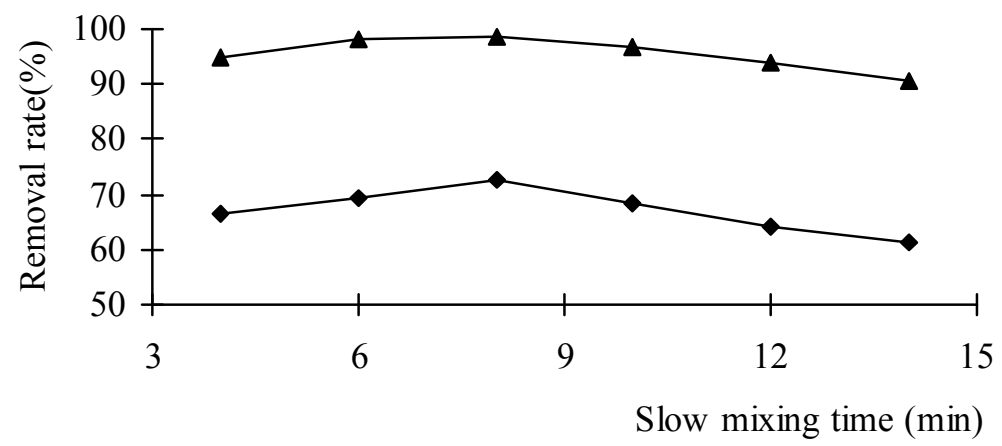

Fig. 6. Influence of slow mixing time on removing COD and SS.

Confirming the optimal dosage of traditional flocculant PAM/PAC. To determine the effect on COD and SS removal using traditional flocculant PAM/ PAC, we initially conducted tests to determine the optimal dosage of traditional flocculant. We prepared six kinds of traditional flocculant (Table 3). And the optimal one was determined. The results indicated that the optimal dosage was $4^{\#}$ traditional flocculant (Table 4). The optimal dosage of traditional flocculant was $8 \mathrm{mg} / \mathrm{L}$ polyacrylamide and $200 \mathrm{mg} / \mathrm{L}$ polyaluminum chloride. 
And the removal rate of COD and SS reached the highest level when treated by $4^{\#}$ traditional flocculant formula. The optimal removal efficiencies for COD and SS were $57.3 \%$ and $92.1 \%$ respectively.

Table 3. Dosage of 6 kinds of traditional flocculant

\begin{tabular}{|c|c|c|}
\hline \multirow{2}{*}{ No.of flocculant } & Dosage of PAM & Dosage of PAC \\
\cline { 2 - 3 } & \multicolumn{2}{|c|}{$\mathrm{mg} / \mathrm{L}$} \\
\hline $1^{\#}$ & 2.0 & 50 \\
\hline $2^{\#}$ & 4.0 & 100 \\
\hline $3^{\#}$ & 6.0 & 150 \\
\hline $4^{\#}$ & 8.0 & 200 \\
\hline $5^{\#}$ & 10.0 & 250 \\
\hline $6^{\#}$ & 12.0 & 300 \\
\hline
\end{tabular}

Table 4. Comparison of the coagulating effect of 6 kinds of traditional flocculant

\begin{tabular}{|c|c|c|c|}
\hline \multirow{2}{*}{ No. } & \multirow{2}{*}{ No.of flocculant } & Removal rate of COD & Removal rate of SS \\
\cline { 3 - 4 } & & \multicolumn{2}{|c|}{$\%$} \\
\hline 1 & $1^{\#}$ & 50.7 & 86.3 \\
\hline 2 & $2^{\#}$ & 52.2 & 88.5 \\
\hline 3 & $3^{\#}$ & 55.4 & 90.9 \\
\hline 4 & $4^{\#}$ & 57.3 & 92.1 \\
\hline 5 & $5^{\#}$ & 54.7 & 89.8 \\
\hline 6 & $6^{\#}$ & 51.9 & 87.6 \\
\hline
\end{tabular}

Comparison of flocculation effect and cost between composite flocculant and traditional flocculant. To achieve the advantages of composite flocculant, we treated the raw water with composite flocculant and traditional flocculant respectively and calculated the cost of treating 1 ton of papermaking wastewater. Table 5 showed that compared with the traditional flocculant PAM/PAC, the removal rate of COD and SS with composite flocculant was increased by $15.2 \%$ and $6.4 \%$ respectively, and the cost was decreased by $18.4 \%$. The advantage of cost-performance ratio was so obvious. So this composite flocculant has a significant application values and market prospects in papermaking wastewater treatment fields. 
Table 5. Comparison of flocculation effect and cost

\begin{tabular}{|l|c|c|c|}
\hline \multirow{2}{*}{$\begin{array}{c}\text { Flocculant's } \\
\text { category }\end{array}$} & Removal rate of COD & Removal rate of SS & $\begin{array}{c}\text { Cost of treating 1 ton } \\
\text { of wastewater (\$) }\end{array}$ \\
\cline { 2 - 3 } PFS/PAM/CTS & 72.5 & 98.5 & 0.047 \\
\hline PAM/PAC & 57.3 & 92.1 & 0.057 \\
\hline
\end{tabular}

The mechanism of flocculation analyses. According to the adsorption theory of flocculant $[14,15]$, flocculation effect of composite flocculants is generally better than that of single used flocculants, and "inorganic/organic" composite flocculants is superior to "inorganic/inorganic" and "organic/ organic", since inorganic flocculants' function to adsorb colloid is better than that of organic, but its chelating and bridging function is inferior to that of organic macromolecule flocculants. Organic macromolecule flocculants make it easier to turn off stability and initiate flocculation with the existence of several inorganic flocculants such as electrolyte salts. Moreover, organic macromolecule flocculants plays a positive role in neutralizing and reducing the surface charge of colloid, compressing double electrode layer of colloid and making them easier to destabilize, flocculation and sediment via middle bridges activity [16]. Therefore, the combined use of inorganic and organic flocculants has complementary advantages and synergism to improve the flocculation and settling performance. With the application of PFS with adsorption effect and PAM /CTS with bridge activity, the composite flocculant can flocculate small colloid into bigger flocs and increase the degree of polymerization and cohesive force of the flocs, which can significantly promote depositing velocity and adsorption rate [17]. Above all make it is characterized by super quality and competitive price.

In addition, there are many hydroxyl groups $(-\mathrm{OH})$ on the molecular chain in chitosan's molecular structure, it can form hydrogen bond with the substances contained $-\mathrm{NH}_{2}$ and $-\mathrm{COOH}$ groups such as amino acid in water, which is able to adsorb and precipitate the substances so as to remove the organics and improve the removal rate of COD [18].

Above two factors and mechanisms jointly contributes to the higher removal rate of COD and SS with the novel composite flocculant than that of traditional flocculant. 


\section{Conclusions}

A new composite flocculant made by ourselves for treating papermaking wastewater has higher cost-performance ratio than traditional flocculant. In the process of preparation, $60 \mathrm{mg} / \mathrm{L}$ of PFS, $2 \mathrm{mg} / \mathrm{L}$ of PAM and $0.4 \mathrm{mg} / \mathrm{L}$ of CTS are the optimal dosage, and the optimal $\mathrm{pH}$ value is adjusted to 7.5 , the optimal rapid stirring speed and slow stirring speed are $100 \mathrm{r} / \mathrm{min}$ and $50 \mathrm{r} / \mathrm{min}$ respectively, rapid mixing time and slow mixing time are 2 min and $8 \mathrm{~min}$ respectively. Under the conditions, compared with the conventional flocculant $\mathrm{PAC} / \mathrm{PAM}$, the removal rate of COD and SS with this novel composite flocculant were increased by $15.2 \%$ and $6.4 \%$ respectively, its input cost was decreased by $18.4 \%$. So this composite flocculant has obviously environmental and economic benefits and has a significant application values and market prospects in papermaking wastewater treatment areas.

\section{Acknowledgements}

This project was supported through ministry of science and technology in P.R. China of SME technology innovation foundation and department of science and technology in Hubei province, P.R.China of science and technology research foundation, which we thank together in this.

Резюме. Изучен коагулирующий эффект новой смеси флокулянтов при очистке сточных вод бумажного производства. Результаты исследований показали, что наибольший коагулирующий эффект достигался при следующем составе смеси коагулянтов: 60 мг/дм³ полимеризованного сульфата железа, 2 мг/дм ${ }^{3}$ полиакриламида, 0,4 мг/дм ${ }^{3}$ хитозана и значении $\mathrm{pH}$ сточных вод 7,5. Также установлено, что ХПК и степень извлечения взвешенных веществ новой смесью флокулянтов составляли соответственно 72,5 и 98,5\%. По сравнению с традиционными флокулянтами, такими, как полиакриламид/полиалюминий хлорид ХПК и степень извлечения взвешенных веществ с помощью этой смеси флокулянтов повысились соответственно на 15,2 и 6,4\%. Кроме того, ее стоимость по сравнению с традиционными флокулянтами была ниже на 18,4\%. Таким образом новая смесь флокулянтов имеет значительные экологические преимущества и экономически эффективна.

Резюме. Вивчено коагулюючий ефект нової суміші флокулянтів при очищенні стічних вод паперового виробництва. Результати досліджень показали, що найбільший коагулюючий ефект досягався при такому складі 
суміші коагулянтів: 60 мг/дм³ полімеризованого сульфату заліза, 2 мг/дм³ полі-акріламіда, 0, 4 мг/дм³ хитозана і значенні $\mathrm{pH}$ стічних вод 7,5. Також встановлено, що ХПК і ступінь вилучення зважених речовин нової сумішшю флокулянтів становили відповідно 72,5 і 98,5\%. У порівнянні 3 традиційними флокулянтами, такими, як поліакриламід/поліалюміній хлорид, ХПК і ступінь вилучення зважених речовин за допомогою цієї суміші флокулянтів підвищилася відповідно на 15,2 і 6,4\%. Крім того, їі вартість в порівнянні з традиційними флокулянтами була нижчою на $18,4 \%$. Таким чином, нова суміш флокулянтів має значні екологічні переваги та економічно ефективна.

\section{References}

[1] Zhao Y. // Paper Chem. - 2009. - 21, N 2. - P. 21 - 25.

[2] Li C. C., Shen W. H., Chen X. Q. // China Pulp and Paper. - 2009. - 28, N 8. P. $65-72$.

[3] Matsushita Y., Iwatsuki A., Yasuda S. //Jap. Wood Res. Soc. - 2004. - 50. P. $540-544$.

[4] Lu Y., Meng L. L., Qiao F. Z. //Technol. Water Treatment. - 2009. - 35, N 7. P. $9-12$.

[5] Yang X. W., Shen Y. D., Li P. Z. // Polymer Bull. - 2010. - 65, N 2. - P. 111 - 122.

[6] Shi Z. L., Wang C. S., Yao S. H. // J. Shenyang Institute Chem. Technol. - 2007. 21, N 2. - P. 3 - 4.

[7] Simphiwe P. B., Ademola O. O., Balakrishna P. // Biotechnol. and Bioproc. Eng. - 2010. - 15. - P. $874-881$.

[8] Yao S. H., Song S. Z. // J. Northeastern University. - 2004. - 25, N12. - P. 1 - 2.

[9] Yang X. X., Hua T., Zhou Q. X. // Technol. Water Treatment. - 2007. - 33, N 12. - P. $11-14$.

[10] Хи Х. T., Нио L., Нио C. // Environ. Protect. Chem. Ind. - 2009. - 29, N 3. P. $230-234$.

[11] Carlos N., Luis M. S., Elena F.//Chem. Eng. Sci. - 2006. -61, N 8. - P.2522-2532.

[12] Tong R. L., Zhao N. N., Liu C. X. // Hebei Chem. Ind. - 2007. - 30, N3. P. $4-5$.

[13] Ни X. M. // Sci. Press, Beijing. - 2007.

[14] Chen F. // China Petrochem. Press, Beijing. -2000.

[15] Yan R. X. // Chem. Ind. Press, Beijing. -2000.

[16] Peng P., Garnier G. // Langmuir. - 2010. - 26, N 22. - P. 16949 - 16957.

[17] Liang Z., Wang Y. X. // J. Earth Sci. - 2010. - 21, N 3. - P. 340 - 360.

[18] Yupaporn K., Anawat A., Mongkol S. // Cellulose. - 2008. - 15. - P. 599-608. 